\title{
INCREASING METHANE PRODUCTION RATE THROUGH ANAEROBIC DIGESTION OF ACTIVATED HORSE DUNG BY CONVENTIONAL THERMAL AND MICROWAVE PRETREATMENTS
}

\author{
Hend A. M. El-Maghawry ${ }^{1}$ and K. I. Wasfy ${ }^{1}$
}

\begin{abstract}
Conventional thermal, microwave and combination of thermal-microwave pretreatments were performed through anaerobic digestion of activated horse dung for improving biogas production and methane production rate. Evaluation of the different pretreatments was conducted in terms of daily and accumulative biogas productions and methane production rate. Final residual digestate from the digestion was analyzed as a rich fertilizer of macro and micro nutrients (Nitrogen, Phosphorus, Potassium and Calcium).

Results indicated that biogas pretreatment would be a rapid method for enhancing biogas and methane production compared to without pretreatment. Conventional thermal pretreatment at $185^{\circ} \mathrm{C}$ in combination with microwave pretreatment of 8 minutes gave the highest values of daily biogas production of $2175 \mathrm{~mL} / \mathrm{day}$, accumulated biogas production of $29757 \mathrm{~mL}$, methane percentage of $83 \%$ and the highest concentration of nitrogen in the final residual digestate of $5.15 \%$ as a rich fertilizer.
\end{abstract}

Keywords: Pretreatments, Microwave, Thermal treatment, Methane production, Chemical analysis

\section{INTRODUCTION}

W orld energy demand is increasing as a result of expansion of high energy intensive industries. Positive aspects coupled with the recent concerns on rapid population growth and increasing energy demand have promoted further research on the anaerobic digestion process development in order to enhance biogas production, achieve faster degradation rates and reduce the amount of final residue to be disposed (Carrere et al., 2010). Anaerobic digestion is a biological process that can degrade waste organic material by the

\section{${ }^{1}$ Lecturer of Agric. Eng., Fac. of Agric., Zagazig Univ.}


concerted action of a wide range of microorganisms in the absence of oxygen. Hydrolysis is the rate-limiting step of anaerobic digestion of semi-solid wastes. In this step both solubilization of particulate matter and biological decomposition of organic polymers to monomers or dimers take place. Thermal, chemical, biological and mechanical pretreatments, as well as combinations of these have been accelerated dung hydrolysis. These Pretreatments cause the lysis or disintegration of dung cells permitting the release of intracellular matter that becomes more accessible to anaerobic microorganisms. This fact improves the overall digestion process velocity and the degree of dung degradation, thus reducing hydraulic retention time (HRT) and increasing methane production rates (Muller, 2000).

Regarding the effect of conventional thermal pretreatment on the performance of anaerobic digestion, Garrote et al. (1999) reported that in pure thermal pretreatment, the substrate is heated (typically 125 to 190 ${ }^{\circ} \mathrm{C}$ ) under pressure and held at that temperature for up to one hour. Ferrer et al. (2008) investigated the effect of a low temperature pretreatment $\left(70^{\circ} \mathrm{C}\right)$ on the efficiency of thermophilic anaerobic digestion (AD) of primary and secondary waste dung. Results suggest that a short period (9h) low temperature pretreatment should be enough to enhance methane production through thermophilic anaerobic digestion of dung. Pilli et al. (2014) stated that the conventional thermal pretreatment is aimed to search the optimum treatment temperature in facilitating the biogas volume, most of studies of the temperature range from 160 to $180^{\circ} \mathrm{C}$ and the treatment time for $30-60 \mathrm{~min}$. Li et al. (2016) studied the gas condition of dung by thermal pretreatment and compared a large difference among the maximum cumulative methane production in the dung of high temperature thermal treatment. The optimum methane production was obtained from $160^{\circ} \mathrm{C}$, while $120^{\circ} \mathrm{C}$ was worse in the methane production.

Relating to microwave (MW) pretreatment, Li et al. (2012) performed conventional thermal and MW methods on raw material. Conventional thermal pretreatment showed an increasing effect on maximum biogas production rate and total produced methane, with an improvement of around $7 \%$ and $8 \%$, respectively. MW pretreatment showed an increasing 
effect on maximum production rate and total produced methane by $18 \%$ and $12 \%$, respectively. Passos et al. (2013) evaluated the effect of MW pretreatment on the solubilisation and anaerobic digestion of microalgae bacterial biomass cultivated in high rate algal ponds for wastewater treatment. In biochemical methane potential tests, the initial biogas production rate $(27-75 \%$ increase) and final biogas yield (12-78\% increase) were higher with pretreated biomass.

While in terms of combined pretreatments, Saifuddin and Fazlili (2009) studied the effects of pretreatment of palm oil mill effluent by MW irradiation and ultrasonic on anaerobic digestion. Greatest enhancement in methane production was shown by the 3 min MW plus $10 \mathrm{~min}$ ultrasonic treatment. The MW in combination with ultrasonic would be a rapid and economical method for dung pretreatment for enhancement of biogas production. Yeneneh et al. (2013) studied the effect of combined MWultrasonic pretreatment on the anaerobic biodegradability of primary, excess activated and mixed dung. Methane production in pretreated primary dung was significantly greater than the methane yield of the untreated primary dung. Cumulative methane production of pretreated excess activated dung was higher than the methane yield from pretreated mixed dung. Deepanraj et al. (2017) presented the effect of autoclave, MW and ultrasonication on anaerobic digestion of food waste co-digested with poultry manure. The pretreatment of the substrates with autoclave, MW and ultrasonication caused an increase in cumulative biogas production of approximately 4.67, 6.43 and $10.12 \%$ respectively.

As former mentioned, it is very important to look after biogas pretreatments techniques in order to increase methane production rates and reduce anaerobic digestion retention time. So, the aim of the present study is to investigate the effects of pretreatments (Conventional thermal, microwave and combination of thermal-microwave pretreatments) through anaerobic digestion of activated horse dung for improving methane production rate.

\section{MATERIALS AND METHODS}

The present study was carried out under laboratory conditions at the Faculty of Agriculture, Zagazig University, Zagazig city ( $30^{\circ} 2^{\prime} \mathrm{N}$ latitude 
and $31^{\circ} 12^{\prime}$ E longitude), in Eastern Delta, Sharkia Governorate, Egypt using laboratory scale anaerobic digester.

\section{Materials}

\subsection{Raw materials}

The following raw materials were used to prepare the fermentation mixture:

\subsubsection{Horse dung}

Fresh horse dung (HD) samples used in the experimental work were taken from AbuKabir animal farm, Sharkia Governorate, Egypt. The analysis of the collected dung was carried out in laboratory of Veterinary Medicine Faculty, Zagazig University as shown in Table 1. Moisture content (M.C.), Total solids concentrations (TS), Total volatile solids (TVS), Ash, Organic carbon $(\mathrm{OC})$, Total nitrogen $(\mathrm{N})$, Carbon/Nitrogen $(\mathrm{C} / \mathrm{N})$, protein and $\mathrm{pH}$ were determined. HD under study was chosen as the best waste material that can produce maximum amount of biogas production than other dungs (Tanusri and Mandal, 1997).

Table 1. Analysis of the horse dung

\begin{tabular}{cccccccccc}
\hline Dung & \multicolumn{10}{c}{ Items } \\
\cline { 2 - 10 } Type & $\begin{array}{c}\text { M.C., } \\
\boldsymbol{\%}\end{array}$ & $\begin{array}{c}\text { TS, } \\
\boldsymbol{\%}\end{array}$ & $\begin{array}{c}\text { TVS, } \\
\boldsymbol{\%}\end{array}$ & $\begin{array}{c}\text { Ash, } \\
\boldsymbol{\%}\end{array}$ & $\begin{array}{c}\text { OC, } \\
\boldsymbol{\%}\end{array}$ & $\begin{array}{c}\mathbf{N}, \\
\boldsymbol{\%}\end{array}$ & $\begin{array}{c}\text { C/N } \\
\text { ratio }\end{array}$ & $\begin{array}{c}\text { Protein, } \\
\boldsymbol{\%}\end{array}$ & $\mathbf{p H}$ \\
\hline Horse & 77.5 & 22.5 & 81 & 19 & 46.98 & 3.5 & 27 & 20.7 & 6.9 \\
\hline
\end{tabular}

\subsubsection{The used activated starter}

The used activated starter was sugarcane juice. It was high in metabolizable energy, added by $10 \%$ of the effective digester volume with raw HD prior to digestion in order to improve the degradation, accelerate hydrolysis step and increase anaerobic bacteria. The properties of the starter were analyzed and shown in Table 2.

Table 2. Chemical properties of the starter

\begin{tabular}{cccccccccc}
\hline \multirow{3}{*}{ Starter } & \multicolumn{10}{c}{ Items } \\
\cline { 2 - 10 } & $\begin{array}{c}\text { M.C., } \\
\boldsymbol{\%}\end{array}$ & $\begin{array}{c}\text { TS, } \\
\boldsymbol{\%}\end{array}$ & $\begin{array}{c}\text { TVS, } \\
\boldsymbol{\%}\end{array}$ & $\begin{array}{c}\text { Ash, } \\
\boldsymbol{\%}\end{array}$ & $\begin{array}{c}\text { OC, } \\
\boldsymbol{\%}\end{array}$ & $\begin{array}{c}\mathbf{N}, \\
\boldsymbol{\%}\end{array}$ & $\begin{array}{c}\text { C/Natio } \\
\text { ratein, }\end{array}$ & $\begin{array}{c}\text { Protein, } \\
\mathbf{\%}\end{array}$ & \\
\hline Sugarcane & 90.8 & 9.2 & 63.2 & 36.8 & 46.98 & 4.3 & 19 & 28.8 & 6.7 \\
\hline
\end{tabular}

\subsection{Anaerobic digester}

The used experimental fermentation digesters were $2400 \mathrm{~mL}$ total volume and $1800 \mathrm{~mL}$ working volume. The experimental treatments were 
conducted at the small-scale unit as shown in Fig. 1 that would aid in their deployment and subsequent commercial success for upgrading the methane percentage under different biogas pretreatments. The biogas was collected via the side arm which was connected to the graduated cylinder. Biogas production was measured by using water displacement method and its methane content by potassium hydroxide $(\mathrm{KOH})$ solution displacement with concentration of $40 \%$ (Erguder et al. 2001; Okeke and Ezekoye, 2006).

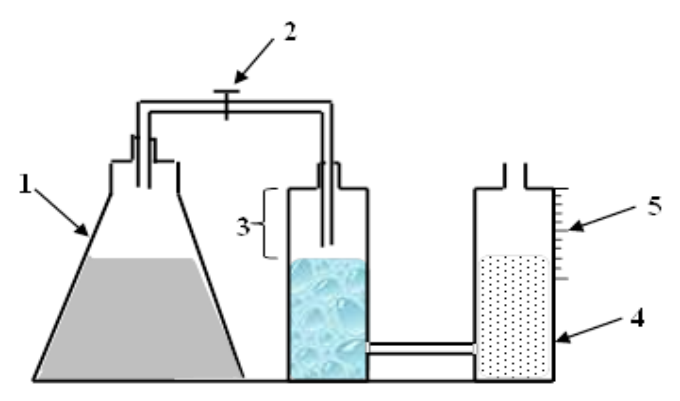

1. Anaerobic digester, 2. Hand valve, 3. Gas gathering place,

4. Calibrated biogas Cylinder, 5. Graduated scale.

Fig. 1. Schematic of biogas digester

\subsection{Thermal oven}

The used thermal oven was used, model WO-05ASS, White Whale type, 220/240V, 50/60HZ, 1600W power and made in Egypt.

\subsection{Microwave}

The used MW of the substrates under study, model KOC-185V, Daewoo type, $50 \mathrm{MHz}, 1000 \mathrm{~W}$ power and made in Egypt.

\section{Methods}

\subsection{Experimental setup}

To investigate the effect of pretreatments on biogas production, the following treatments were carried out as follow:

\subsubsection{Control test}

Control test (without pretreatment) was done to compare the production rates with the used tests pretreatments under study.

\subsubsection{Pretreatments}

For each treatment, $540 \mathrm{~g}$ of HD (raw material) were subjected to the following suggested pretreatments: 


\section{- Conventional thermal pretreatment}

Effects of thermal pretreatment were observed for three different temperatures, namely 125,155 and $185^{\circ} \mathrm{C}\left(O_{125}, O_{155}\right.$ and $\left.O_{185}\right)$. Samples were heated in the the aluminum foil plates for $60 \mathrm{~min}$ and covered well to avoid water evaporation and stirred to ensure temperature homogeneity. After heating period, this dung was cooled down to ambient temperature and mixed with slurry (Almukhtar et al., 2012).

\section{- Microwave pretreatment}

Substrates were subjected to irradiation MW pretreatment using MW for 2, 5 and $8 \mathrm{~min}\left(M W_{2}, M W_{5}\right.$ and $\left.M W_{8}\right)$. When MW pretreatment was completed, the samples were removed and cooled to room temperature.

\section{- Combination of thermal-microwave pretreatment}

For combined oven and MW pretreatments, the samples were heated as mentioned above using electrical oven from 125 to $185^{\circ} \mathrm{C}$. After which each sample was exposed to MW irradiation from 2 to $8 \mathrm{~min}$.

Digesters were run in parallel. They were inoculated with the same anaerobic dung. The experimental procure and preparation steps from raw material to final digestion were illustrated in Fig. 2. First, digesters were fed with raw material and starter (10\% of digester effective volume) in order to acclimate microorganisms and verify the performance of the control reactor. Then, the others were fed with treated dung under different treatments (oven, MW and combined) and starter. The recommended ratio of added tap water to a final volume of $1800 \mathrm{~mL}$ was calculated to be in the ratio of 2:1 (v/w) as (Lo et al., 1981) for obtaining the desired total solids concentration $(7-10 \%)$ :

$D_{w}=R_{m}\left[\left(T S_{r m}-T S_{d i g}\right) / T S_{d i g}\right]$

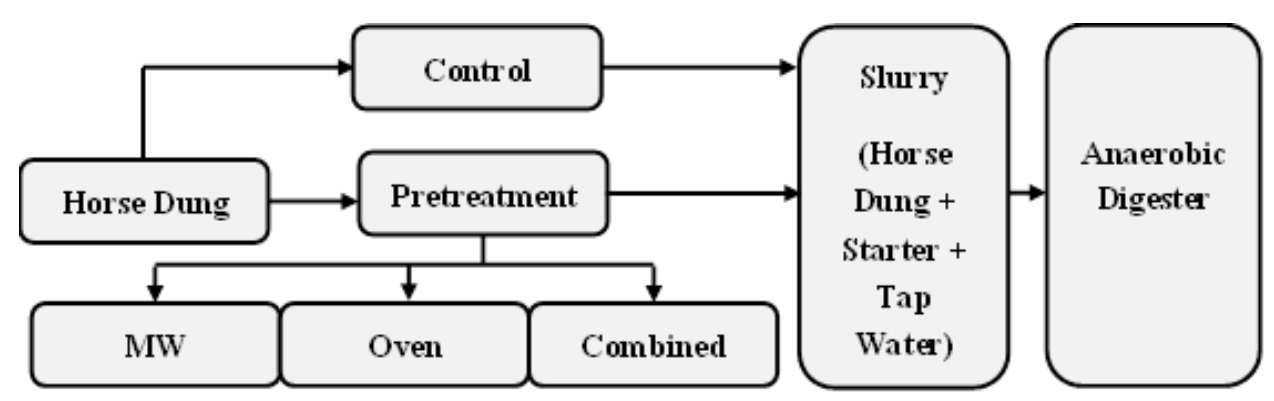

Fig. 2. Preparation steps of digestion 
Where: $D_{w}$ : Amount of required water, $\mathrm{L} ; R_{m}$ : Amount of raw materials added, $\mathrm{kg} ; T S_{r m}$ : Total solids of raw materials, \%; $T S_{d i g}$ : Total solids of fermentation materials, $\%$

All reactors were maintained through fermentation period at mesophilic conditions (room temperature) and $\mathrm{pH}$ of 6.7 (digital $\mathrm{pH}$ meter with model of 915, Cat. 13-636-916.2 and an accuracy of $\pm 0.01 \mathrm{pH}$ unit). They were stirred manually twice a day for keeping the slurry homogeneous. Samples were taken every $24 \mathrm{~h}$ to examine daily biogas production and methane content.

\subsection{Measurements}

\subsubsection{Daily and cumulative biogas production}

The daily and cumulative biogas productions were measured using displacement method.

\subsubsection{Methane percentage}

The percentage of methane $\mathrm{CH}_{4}$ can be estimated through recognition of $\mathrm{CO}_{2}$ percentage from this equation (Konstandt, 1976):

Percentage of $\mathrm{CH}_{4}=100 \%-\left[\mathrm{CO}_{2} \%+\left(3 \% \mathrm{H}_{2} \mathrm{~S}\right.\right.$ and other gases $\left.)\right]$

Where: $3 \%$ is the average of $\mathrm{H}_{2} \mathrm{~S}$ and the other gases which constitute about $1-5 \%$ in the produced gas (GTZ, 1999).

Percentage of $\mathrm{CO}_{2}=\left[\left(V_{1}-V_{2}\right) / V_{1}\right] \times 100$

Where: $V_{1}$ : volume of biogas before removal of $\mathrm{CO}_{2}, \mathrm{~mL}$

$V_{2}$ : volume of methane and the other gases after removal of $\mathrm{CO}_{2}, \mathrm{~mL}$

\subsubsection{Analysis}

\subsubsection{Substrates analysis}

In order to determine substrates composition, several measurements were carried out on samples, according to Standard Methods (APHA et al., 2005).

After drying in an electrical oven at $105^{\circ} \mathrm{C}$ for 24 hours, samples were taken and then weighted using digital balance till reaching the equilibrium to determine total solid mass (TS).

$T S=\left(M_{T S} / M_{f}\right) \times 100$

MTs: Mass of total solids, $\mathrm{g}$

$M_{f}$. Fresh mass, $\mathrm{g}$

Total Volatile solid amount is the amount of combustible material in a sample. It is determined by an analytical method called "loss on ignition" which is the amount of matter that is volatilized and burned from a 
sample exposed to air at $550^{\circ} \mathrm{C}$ for 2 hours. The organic (carbon containing matter) is lost and the remaining matter is the mineral or ash component of the original sample. TVS amount is usually reported as percent of total solids (TS), where TS are the sum of the VS and ash components. The percentage of Organic carbon $(O C)$ was estimated from the percentage of TVS according to (Faure and Deschamps, 1990).

$\mathrm{OC}=T V S / 1.724$

\subsubsection{Gas Composition}

HRT and peak value of the corresponding gas were obtained by using the standard gas component, which can be calculated by the gas component of the fermentation gas.

$\mathrm{CH}_{4}$ percentages were determined for each treatment under study. While the highest values of treatments in biogas production were determined and analyzed from its composition $\left(\mathrm{CH}_{4}, \mathrm{~N}_{2}, \mathrm{CO}_{2}\right.$ and $\left.\mathrm{H}_{2} \mathrm{~S}\right)$ using natural gas meter; $\pm 5 \%$ variance, $12 \mathrm{~V}$ and $1.25 \mathrm{~mA}$ in Petroleum Petrojet Company, located in Suez, Egypt.

\subsubsection{Nutrients analysis}

Final residual digestate from the digestion was analyzed as a rich fertilizer of macro and micro nutrients ( $, \mathrm{P}, \mathrm{K}$ and $\mathrm{Ca}$ ).

\section{- Nitrogen}

Nitrogen $(\mathrm{N})$ is one of the five major elements found in organic materials. Nitrogen content was determined according to Kjeldahl (1883) method.

\section{- Phosphorus, Potassium and Calcium}

The individual elemental content $(\mathrm{P}, \mathrm{K}$ and $\mathrm{Ca}$ ) of residual digestate is determined after digestion with nitric acid $\left(\mathrm{HNO}_{3}\right)$ and hydrogen peroxide $\left(\mathrm{H}_{2} \mathrm{O}_{2}\right)$. The method is adapted from Wolf $\boldsymbol{e t}$ al. (2003).

\section{RESULTS AND DISCUSSION}

Biogas generation from the anaerobic digestion of activated horse dung under conventional thermal and MW pretreatments and combination of them was observed through 24 days. The obtained results will be discussed under the following heads:

\section{Influence of Different Pretreatments on Daily and Accumulative Biogas Productions}

Obtained daily and accumulative biogas productions were discussed under different pretreatments as follow: 


\subsection{Conventional thermal pretreatment}

The daily biogas production as well as accumulative biogas production with conventional thermal pretreatment under different temperatures versus fermentation period comparing to without thermal pretreatment (control) were illustrated in Fig. 3.
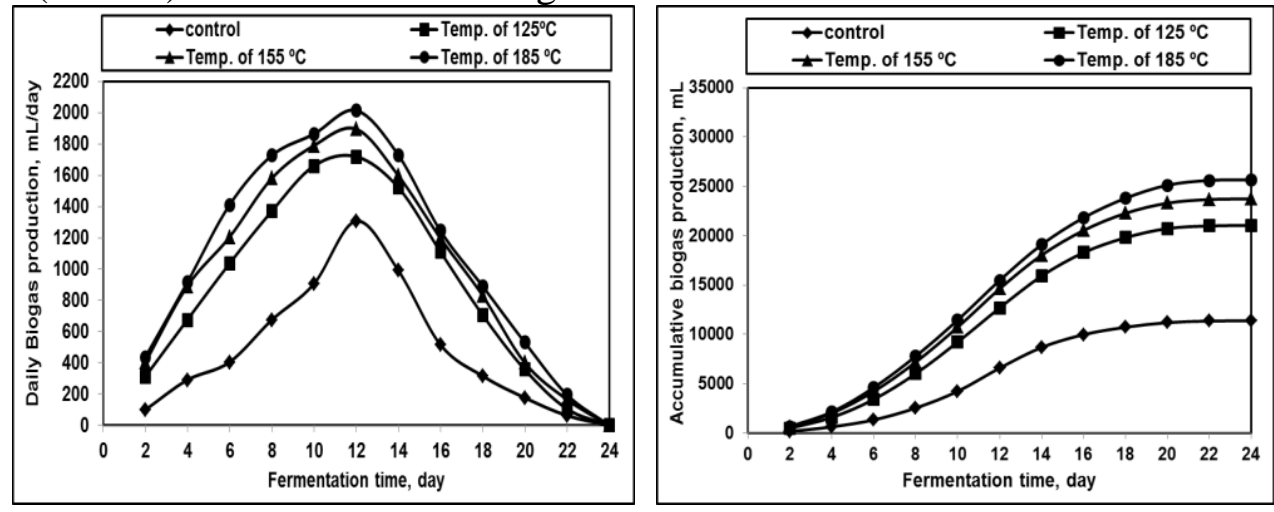

Fig. 3. Daily and accumulative biogas production under conventional thermal pretreatment

The obtained results showed that the daily biogas production values of the different treatment temperatures were very low through the first days and thereafter, started to increase with increasing the fermentation period until reached to their maximum values and then, decreased. The maximum daily biogas production values were 1720, 1896 and $2015 \mathrm{~mL} /$ day for treatment temperatures of 125,155 and $185{ }^{\circ} \mathrm{C}$, respectively. For without thermal pretreatment, the daily biogas production was $1307 \mathrm{~mL} / \mathrm{day}$. The increasing rate of daily biogas production after thermal pretreatment was about 31.60, 45.07 and $54.17 \%$ than that of control test. This is compatible with Bougrier et al. (2008). They stated that treatments at temperatures of $121{ }^{\circ} \mathrm{C}$ which led to a $20-30 \%$ biogas production increase and treatments at $160-180 \circ \mathrm{C}$ which led to a $40-100 \%$ biogas production increase.

Based on daily biogas production, the accumulative biogas was determined. It was clear that accumulative biogas production was gradually increased with fermentation time. It was started from the first day and increased continuously to reach the maximum values at the last day. The maximum accumulated biogas production values were 21049, 
23728 and $25660 \mathrm{~mL}$ for treatment temperatures of 125,155 and $185{ }^{\circ} \mathrm{C}$, respectively. Control treatment gave accumulative biogas production of $11382 \mathrm{~mL}$.

Thermal pre-treatment accelerated the hydrolysis step through digestion, improved the organic solubilization in addition to enhancement of dung disintegration. So, it gave the highest values of daily and accumulated biogas production under different treatment temperatures as compared to without thermal pretreatment. This is in agreement with Garrote $\boldsymbol{e t}$ al. (1999). They reported that the presence of heat and water disrupts the hydrogen bonds that hold together crystalline cellulose and the lignocellulose complexes, causing the biomass to swell.

\subsection{Microwave pretreatment}

Effect of MW pretreatment under different irradiation times on daily and accumulative biogas production comparing to without MW pretreatment (control) was showed in Fig. 4.
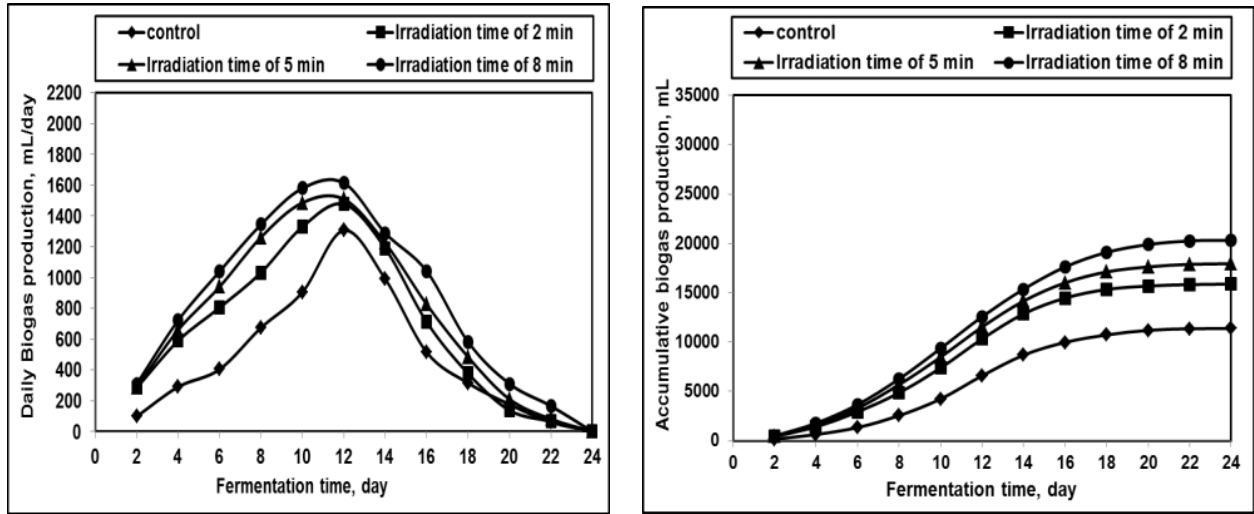

Fig. 4. Daily and accumulative biogas production under microwave irradiation pretreatments

Obtained results showed that the increase of fermentation time from 2 to 12 days was accompanied with an increase in the daily biogas production from 98 to 1307, from 284 to 1477, from 288 to 1510 and from 310 to $1615 \mathrm{~mL} /$ day at the following conditions of control and $\mathrm{MW}_{2}, \mathrm{MW}_{5}$ and $\mathrm{MW}_{8}$, respectively. Any further increase in fermentation time more than 12 days up to 22 days, the biogas daily production values will decrease from 1307 to 62 , from 1477 to 66 , from 1510 to 81 and from 1615 to $166 \mathrm{~mL} /$ day under the same previously mentioned treatments. 
As to the accumulated biogas production, the maximum accumulated biogas production values were 15879, 17937.6 and $20320 \mathrm{~mL}$ for treated times of $\mathrm{MW}_{2}, \mathrm{MW}_{5}$ and $\mathrm{MW}_{8}$, respectively. It was $11382 \mathrm{~mL}$ under without MW pretreatment.

MW pretreatment at all irradiation times of enhanced the biogas production compared to the control. At 8 minutes irradiation time gave the highest value of both daily and accumulated biogas production. This was attributed to that larger molecules and longer chain fatty acids may require further treatment to break into volatile fatty acid. During longer exposure to MW heating some of the long fatty acid chains will also be broken down to short fatty acid chain. These results agreed with Pecorini et al. (2016). They proved that MW pretreatment is highly effective in breaking organic molecules and disrupting complex structures, leading to the release of extracellular and intracellular material, which in turn increases the accessibility and bioavailability of a substrate.

It was revealed that daily and accumulative biogas production values under MW pretreatment were less than conventional thermal pretreatment due to its effect of heat than irradiation on dung samples.

\subsection{Combination of thermal-microwave pretreatments}

The daily biogas and accumulative biogas production under different combination pretreatments comparing with control treatment were indicated as in Fig. 5.

Biogas production values were very low through the first days and thereafter, started to increase with increasing the fermentation period until reached their maximum values and then, decreased.

The maximum daily biogas production values were 1795, 1955 and 1978 $\mathrm{mL} /$ day at treatment temperature of $125{ }^{\circ} \mathrm{C}$ under $\mathrm{MW}_{2}, \mathrm{MW}_{5}$ and $\mathrm{MW}_{8}$, respectively. These values became 1920, 2056 and $2102 \mathrm{~mL} /$ day at treatment temperature of $155{ }^{\circ} \mathrm{C}$. Finally they were 2105,2140 and 2175 $\mathrm{mL} /$ day at treatment temperature of $185^{\circ} \mathrm{C}$ under the same pervious $\mathrm{MW}$ treated times, respectively. While, control treatment gave $1307 \mathrm{~mL} / \mathrm{day}$. With respect to the accumulated biogas production, the maximum values were $21510,23184.3$ and $24183 \mathrm{~mL}$ at treatment temperature of $125{ }^{\circ} \mathrm{C}$, these values were 23522,25251 and $26220 \mathrm{~mL}$ at $155{ }^{\circ} \mathrm{C}$ and they became 25591, 27484 and $29757 \mathrm{~mL}$ at treatment temperature of $185{ }^{\circ} \mathrm{C}$ 
under $\mathrm{MW}_{2}, \mathrm{MW}_{5}$ and $\mathrm{MW}_{8}$, in that order. For without combination pretreatment, the accumulative biogas production reached to $11382 \mathrm{~mL}$. Results revealed that without combination pretreatment gave the lowest values of daily and accumulative biogas production as compared to the combination pretreatment.
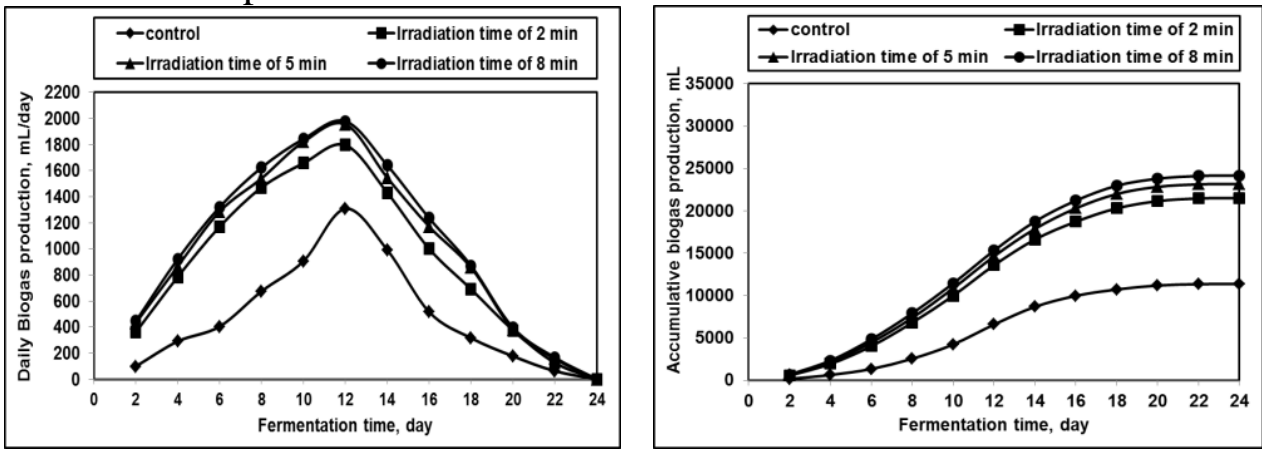

a. Combination of $125^{\circ} \mathrm{C}$ with 2,5 and 8 min
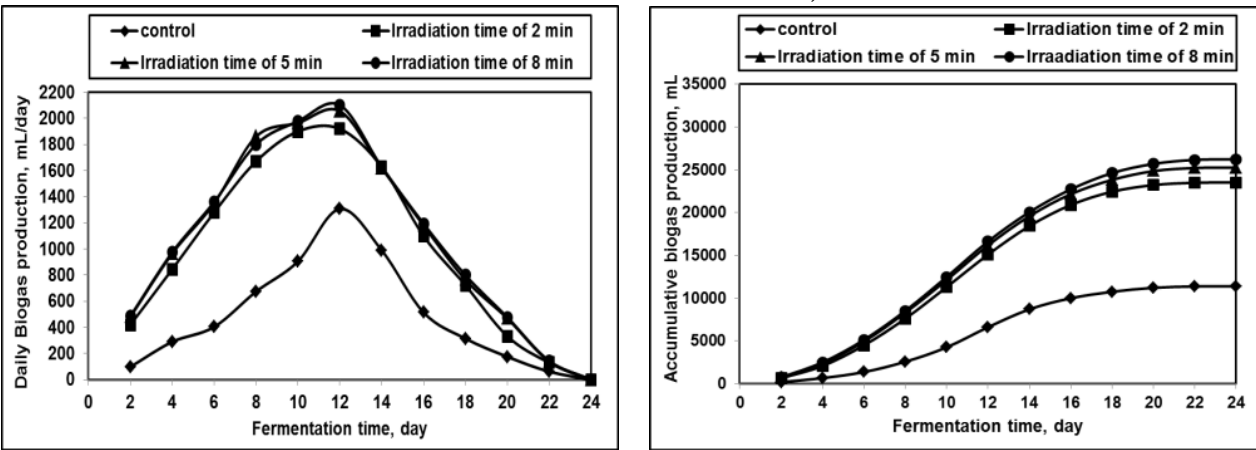

b. Combination of $155^{\circ} \mathrm{C}$ with 2,5 and 8 min
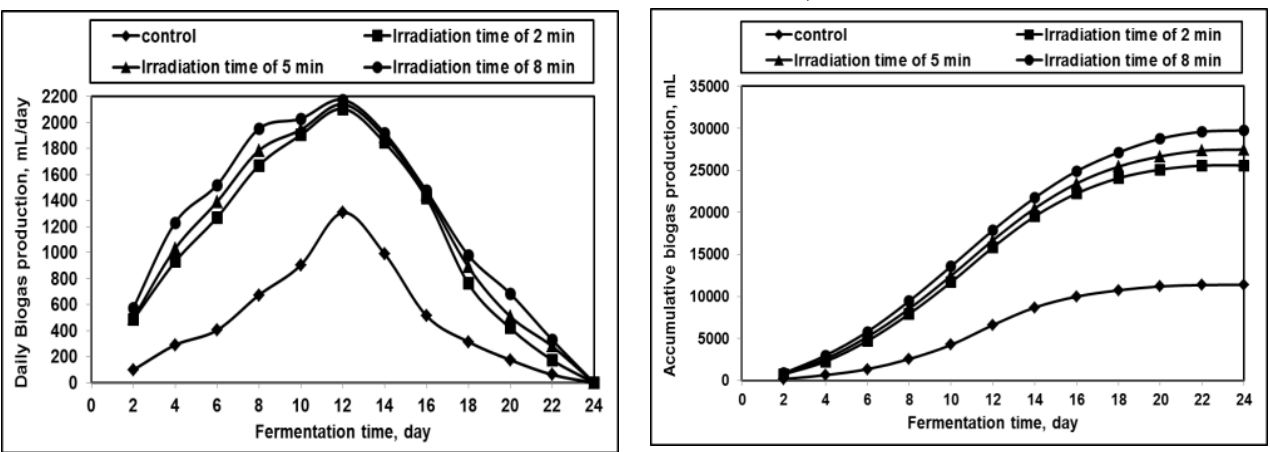

c. Combination of $185^{\circ} \mathrm{C}$ with 2,5 and $8 \mathrm{~min}$

Fig. 5. Effect of combination pretreatment on daily and accumulative biogas production through fermentation time 
Combination pretreatment at $185^{\circ} \mathrm{C}$ with $\mathrm{MW}_{8}$ gave the highest value of daily and accumulated biogas production. Conventional thermal pretreatment in combination with MW pretreatment would be a rapid method for enhancing biogas production. So, the application of more than one treatment resulted in improving dung biodegradation, cell wall disruption and release of organics due to the complementary synergy between the treatment techniques that are combined.

\section{Influence of Different Pretreatments on Methane Percentage}

The methane production rate was influenced by the following pretreatments as follow:

\subsection{Conventional thermal pretreatment}

Methane percentage versus fermentation time under all temperature values of thermal pretreatment was shown in Fig. 6. At fermentation time from 2 to 12 days, methane percentage was ranged from 25 to 71,34 to 77 , from 36 to 79 and from 40 to $82.2 \%$ under control and temperatures of 125,155 and $185^{\circ} \mathrm{C}$, respectively. The further increase in fermentation time up to 22 days, it was decreased from 71 to 31 , from 77 to 40 , from 79 to 42 and from 82.2 to $47 \%$, under the same previously circumstances. Results revealed that all temperature values of thermal pretreatment enhanced the methane production rate relative to the control. Treatment temperature of $185^{\circ} \mathrm{C}$ gave the highest methane percentage compared to other treatments under study.

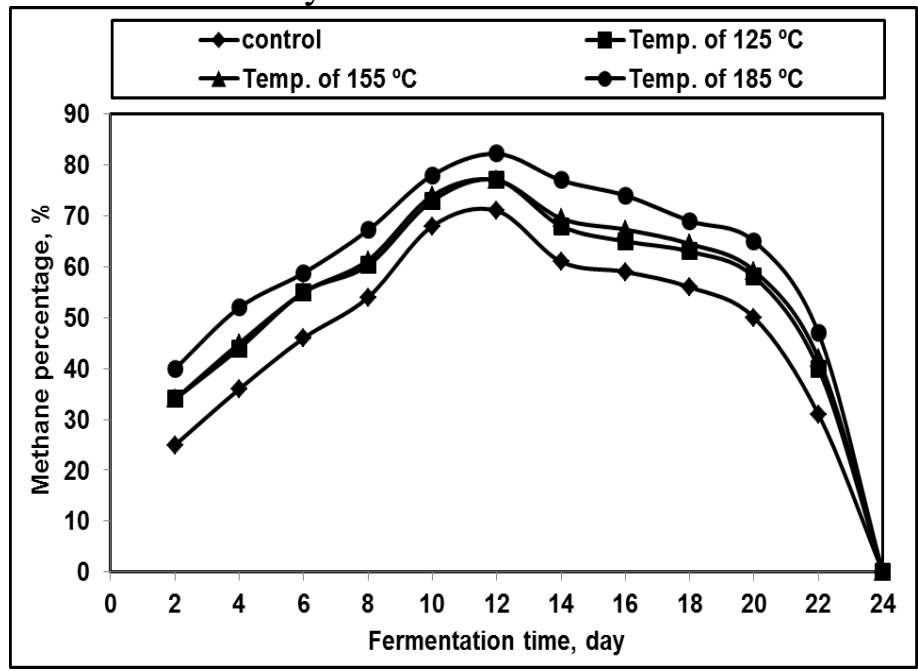

Fig. 6. Methane percentage under different conventional thermal pretreatment 


\subsection{Microwave pretreatment}

Effect of different irradiation times on methane percentage through fermentation time was presented in Fig. 7.

Results showed that MW pretreatment enhanced the methane percentage compared to control treatment. The highest percentage of methane was $72,74.6$ and $76.8 \%$ for irradiation times of 2, 5 and 8 minutes, while it was $71 \%$ for without MW pretreatment. The highest value of methane percentage was observed at irradiation time of 8 minutes.

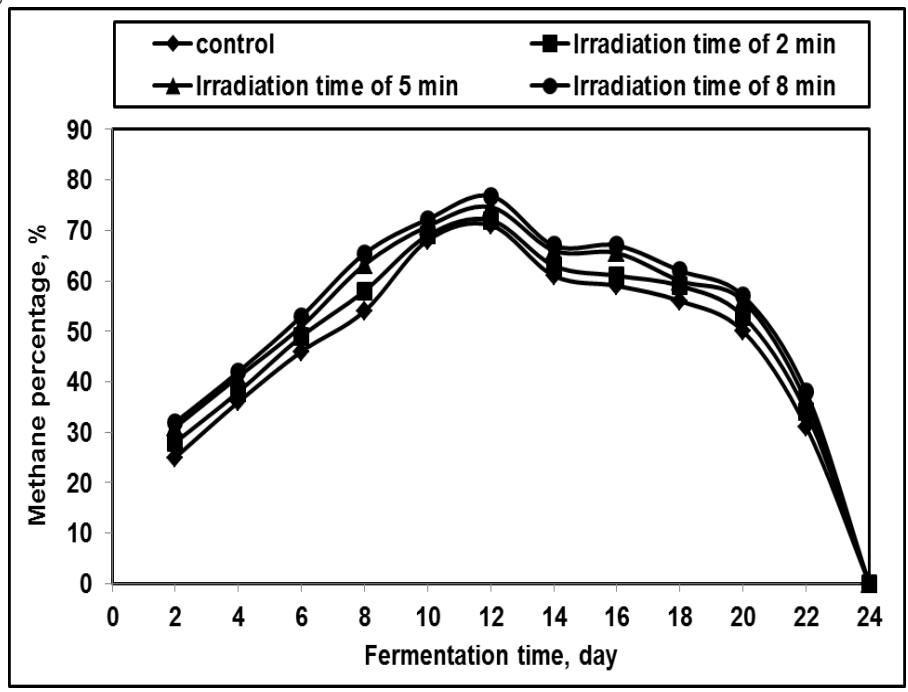

Fig. 7. Variation of methane percentage under microwave irradiation times

It was obvious that MW pretreatment gave the lowest percentage of methane than conventional thermal pretreatment.

\subsection{Combination of thermal-microwave pretreatment}

Methane percentage versus fermentation time was given through various irradiation times for all combined effects of thermal-microwave pretreatment in Fig. 8 .

Obtained results showed that the highest percentages of methane were 80, 81.5 and $83 \%$ that observed under combination of temperatures of 125 155 and $185^{\circ} \mathrm{C}$ with $\mathrm{MW}_{8}$. This is attributed to these conditions enhanced daily biogas production, and thus increases methane production as well. Combination of thermal-microwave pretreatment at $185^{\circ} \mathrm{C}$ with $\mathrm{MW}_{8}$ 
showed an increasing effect on maximum methane produced with an improvement of around $12 \%$ comparing with control treatment.

\section{Chemical Analysis}

Chemical analysis was done to the collected gas and residual digestate in order to study the effect of biogas pretreatments on their quality as follow:

\subsection{Influence of different pretreatments on gas composition}

Samples of the collected gas were taken after 12 days of batch operation. The highest values of biogas production under different treatments were chosen to be analyzed as shown in Table 3 .

Results of the gas chemical analysis showed that combination of thermalmicrowave pretreatment improved the biogas properties as it increased methane percentage and decreased both $\mathrm{CO}_{2}$ and $\mathrm{H}_{2} \mathrm{~S}$.

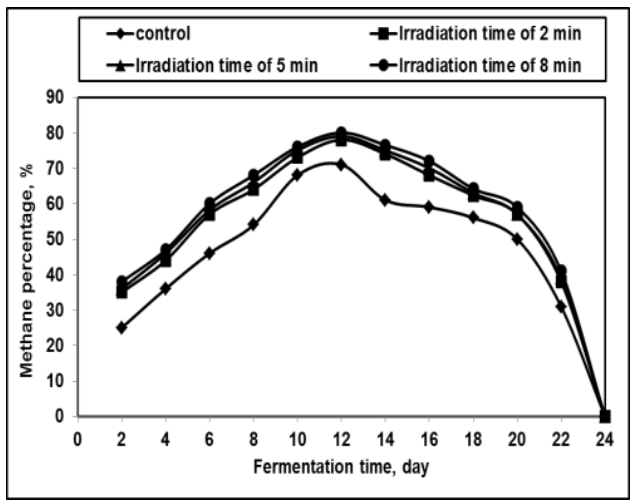

a. Combination treatment at $125^{\circ} \mathrm{C}$

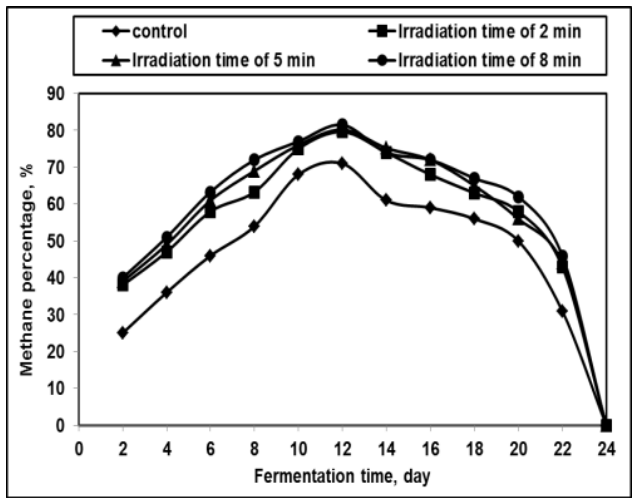

b. Combination treatment at $155^{\circ} \mathrm{C}$

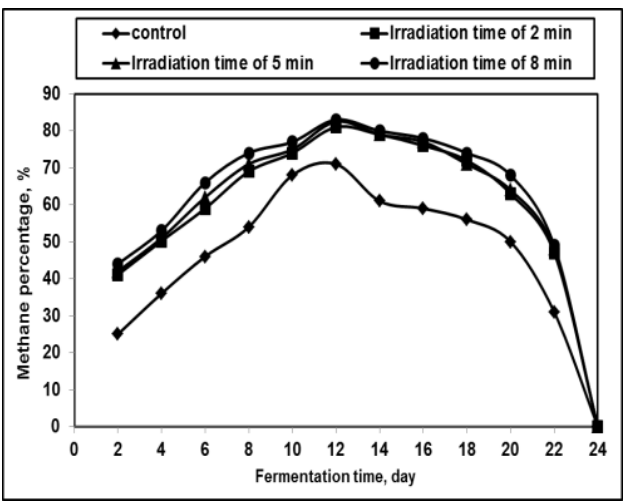

c. Combination treatment at $185^{\circ} \mathrm{C}$

Fig. 8. Effect of combination pretreatment on methane percentage 
Table 3. Chemical analysis of the collected gas

\begin{tabular}{|c|c|c|c|c|c|c|}
\hline \multirow{2}{*}{\multicolumn{3}{|c|}{ Treatments }} & \multicolumn{4}{|c|}{ Gas properties, \% } \\
\hline & & & \multirow{2}{*}{$\begin{array}{l}\mathbf{C H}_{\mathbf{4}} \\
82.2\end{array}$} & \multirow{2}{*}{$\frac{\mathbf{N}_{2}}{1.77}$} & \multirow{2}{*}{$\begin{array}{c}\mathbf{C O}_{2} \\
15.74 \\
\end{array}$} & \multirow{2}{*}{$\begin{array}{l}\mathbf{H}_{2} \mathbf{S} \\
0.29\end{array}$} \\
\hline & & $\mathrm{O}_{185}$ & & & & \\
\hline \multirow{5}{*}{ 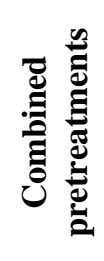 } & \multirow{2}{*}{$0^{\frac{6}{n}}$} & $\mathbf{M W}_{5}$ & 80.2 & 1.91 & 17.57 & 0.32 \\
\hline & & $\mathrm{MW}_{8}$ & 81.5 & 1.82 & 16.30 & 0.38 \\
\hline & \multirow{3}{*}{$0^{\infty}$} & $\mathbf{M W}_{2}$ & 81.0 & 1.86 & 16.79 & 0.35 \\
\hline & & $\mathbf{M W}_{5}$ & 82.5 & 1.75 & 15.46 & 0.29 \\
\hline & & $\mathbf{M W}_{8}$ & 83.0 & 1.79 & 14.93 & 0.28 \\
\hline
\end{tabular}

Combination of thermal - microwave treatment temperature of $185{ }^{\circ} \mathrm{C}$ with $\mathrm{MW}_{8}$ gave the highest percentage of methane of $83 \%$ and the lowest values of both $\mathrm{CO}_{2}(14.93 \%)$ and $\mathrm{H}_{2} \mathrm{~S}(0.24 \%)$ compared to other treatments.

\subsection{Residual digestate characteristics under different treatments}

The residual digestate was determined as nutrients values which considered a good rich fertilizer as illustrated in Table 4 .

Table 4. Chemical analysis of the residual digestate

\begin{tabular}{|c|c|c|c|c|c|c|}
\hline \multirow{2}{*}{\multicolumn{3}{|c|}{ Treatments }} & \multicolumn{4}{|c|}{ Chemical analysis, \% } \\
\hline & & & $\mathbf{N}$ & $\mathbf{P}$ & $\mathbf{K}$ & $\mathbf{C a}$ \\
\hline \multicolumn{3}{|c|}{ Control } & 3.40 & 0.60 & 1.20 & 1.40 \\
\hline \multirow{3}{*}{\multicolumn{2}{|c|}{$\sum$}} & $\mathrm{MW}_{2}$ & 3.80 & 0.56 & 1.56 & 1.40 \\
\hline & & $\mathbf{M W}_{5}$ & 4.00 & 0.62 & 1.50 & 1.45 \\
\hline & & $\mathbf{M W}_{8}$ & 4.20 & 0.65 & 1.60 & 1.50 \\
\hline \multirow{3}{*}{\multicolumn{2}{|c|}{$\overbrace{0}^{\Xi}$}} & $\mathbf{O}_{125}$ & 4.40 & 0.66 & 1.70 & 1.50 \\
\hline & & $\mathbf{O}_{155}$ & 4.60 & 0.65 & 1.82 & 1.70 \\
\hline & & $O_{185}$ & 4.80 & 0.70 & 1.90 & 1.80 \\
\hline \multirow{9}{*}{ 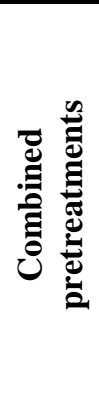 } & \multirow{3}{*}{$0^{20}$} & $\mathbf{M W}_{2}$ & 4.40 & 0.62 & 1.60 & 1.55 \\
\hline & & $\mathbf{M W}_{5}$ & 4.45 & 0.64 & 1.60 & 1.60 \\
\hline & & $\mathbf{M W}_{8}$ & 4.60 & 0.68 & 1.70 & 1.60 \\
\hline & \multirow{3}{*}{$0^{\frac{1}{2}}$} & $\mathbf{M W}_{2}$ & 4.66 & 0.65 & 1.80 & 1.75 \\
\hline & & $\mathbf{M W}_{5}$ & 4.70 & 0.66 & 1.84 & 1.70 \\
\hline & & $\mathbf{M W}_{8}$ & 4.85 & 0.68 & 1.90 & 1.76 \\
\hline & \multirow{3}{*}{$0^{\infty}$} & $\mathrm{MW}_{2}$ & 4.70 & 0.72 & 1.90 & 1.82 \\
\hline & & $\mathbf{M W}_{5}$ & 4.90 & 0.72 & 2.00 & 1.85 \\
\hline & & $\mathbf{M W}_{8}$ & 5.15 & 0.74 & 2.00 & 1.90 \\
\hline
\end{tabular}

Results of the residual digestate chemical analysis showed that the combination of thermal-microwave pretreatment enhanced macro and micro nutrients (Nitrogen, Phosphorus, Potassium and Calcium). It means that the residual digestate could be used as a rich organic fertilizer. 
High concentration of nutrients gave high potential of the residual digestate as fertilizer that could be used for soil improvement.

Nutrient concentration increased slightly during digestion because of the loss of volatile solids, associated with methane generation.

It was evident that the use of conventional thermal pretreatment improved the properties of residual digestate than MW pretreatment. The highest percentages of $\mathrm{N}, \mathrm{P}, \mathrm{K}$ and $\mathrm{Ca}$ under $185^{\circ} \mathrm{C}$ thermal pretreatment were 4.80, 0.70, 1.90 and $1.80 \%$, respectively. While under using $\mathrm{MW}_{8}$ pretreatment, the values were $4.20,0.65,1.60$ and $1.50 \%$, in that order. The total nitrogen in the treated samples is higher than in the non-treated samples. This is expected that the thermal pre-treatment did impact cell biodegradability in some way.

Combination of conventional thermal treatment at $185^{\circ} \mathrm{C}$ with $\mathrm{MW}_{8}$ gave the highest values of $\mathrm{N}, \mathrm{P}, \mathrm{K}$ and $\mathrm{Ca}$ of 5.15, 0.74, 2.00 and $1.90 \%$ compared to other treatments.

\section{CONCLUSION}

Based on the achieved and obtained results, it could be concluded to the following:

- Biogas pretreatments gave the highest production and methane percentage comparing with control (without pretreatment).

- For biogas pretreatment using only conventional thermal method, treating with $185^{\circ} \mathrm{C}$ gave sufficient biogas production.

- For biogas pretreatment using only microwave method, treating with irradiation time by 8 minutes gave the sufficient methane percentage.

- The authors recommended to use combination of conventional thermal pretreatment with microwave pretreatment $\left(185^{\circ} \mathrm{C}\right.$ temperature with 8 minutes irradiation time) as a rapid method for increasing biogas and methane productions as well as the highest concentration of elements $(\mathrm{N}, \mathrm{P}, \mathrm{K}$ and $\mathrm{Ca}$ ) in the final residual digestate to be rich fertilizer compared with other pretreatments.

\section{REFERENCES}

Almukhtar, R. S; A. A. Alwasiti and M. T. Naser (2012). Enhancement of biogas production and organic reduction of sludge by different pre-treatment processes. Iraqi Journal of Chemical and Petroleum Engineering, 13 (1): $19-31$. 
APHA, AWWA and WEF (2005). Standard methods for examination of water and wastewater, $21^{\mathrm{Ed}}$. American Public Association (APAH), American Water Work Association (AWWA) and Water Environmental Federation (WEF), Washington DC.

Bougrier, C; J. P. Delgenes and H. Carrere (2008). Effects of thermal treatments on five different waste activated sludge samples solubilisation, physical properties and anaerobic digestion, Chemical Engineering Journal, 139: 236-244

Carrere, H; C. Dumas, A. Battimelli, D. J. Batsone, J. P. Delgene and J. P. Steyer (2010). Pretreatment methods to improve sludge anaerobic degradability: a review. J. Hazard Mater, 183: $1-15$.

Deepanraj, B; V. Sivasubramanian and S. Jayaraj (2017). Effect of substrate pretreatment on biogas production through anaerobic digestion of food waste. International Journal of Hydrogen Energy.

Erguder, T. H; U. Tezel, E. Guven and G. N. Demirer (2001). Anaerobic biotransformation and methane generation potential of cheese whey in batch and UASB reactors. Waste Management, 21: $643-650$.

Faure, D. and A. M. Deschamps (1990). Physicochemical and microbiological aspects in composting of grape pulps. Biol. Wastes, 34: $251-258$.

Ferrer, I; S. Ponsá, F. Vázquez, and X. Font (2008). Increasing biogas production by thermal $\left(70^{\circ} \mathrm{C}\right)$ sludge pretreatment prior to thermophilic anaerobic digestion. Biochemical Eng. Journal, 42: $186-192$.

Garrote, G; H. Dominguez, and J. C. Parajo (1999). Hydrothermal processing of lignocellulosic materials. Holz als Roh- und Werkstoff, 57: $191-202$.

GTZ, G. (1999). Biogas Digest (Volume I. Biogas Basics) GTZ-GATE. Eschborn, Germany, http://www.gtz.de/dokumente/bib/04-5364.

Kjeldahl, J. (1883). Neue Methods zur Bestimmung des Stickstoffs in Organischen Korpern. Z. Anal. Chem., 22: 366 - 382.

Konstandt, H. G. (1976). Engineering's operation and economics of methane gas production. Seminar on Microbial Energy Conversion, Gottingen, Erich Goetze Verlag, Germany. 
Li, J; Y. Zeng, W. Liu, Y. Wang, Y. Zheng, C. Liu and Y. Zhao (2016). Effect of methanogenesis of residue from thermal pretreatment sludge by anaerobic fermentative hydrogen production, Procedia Environmental Sciences 31, 318 - 324.

Li, L; X. Kong, F. Yang, D. Li, Z. Yuan and Y. Sun (2012). Biogas Production potential and kinetics of microwave and conventional thermal pretreatment of grass, Appl. Bio-chem. Bio-technol., 166:1183 - 1191 .

Lo, K. V; W. M. Carson and K. Jeffers (1981). A computer-aided design for biogas production from animal manure. Livestock Wastes. A Renewable Resource, 141: 133 - 135.

Muller, J. A. (2000). Pretreatment processes for recycling and reuse of sewage sludge, Water Sci. Technol., 42: 167 - 174.

Okeke, C. E. and V. A. Ezekoye (2006). Design, construction and performance evaluation of plastic biodigester. The Pacific Jo. Sc. Tec., 7(2): Nsukka, Nigeria.

Passos, F; M. Solé, J. García and I. Ferrer (2013). Biogas production from microalgae grown in wastewater: Effect of microwave pretreatment. Applied Energy, 108: 168 - 175 .

Pecorini, I; F. Baldi, E. A. Carnevale and A. Corti (2016). Biochemical methane potential tests of different autoclaved and microwaved lignocellulosic organic fractions of municipal solid waste. Waste Manage, 56: 143 - 150.

Pilli, S; S. Yan, R. D. Tyagi and R. Y. Surampalli (2014). Thermal Pretreatment of Sewage Sludge to Enhance Anaerobic Digestion: A Review. Critical Reviews in Environ Sci Technol., 45: 669 - 702.

Saifuddin, N. and S. A. Fazlili (2009). Effect of microwave and ultrasonic pretreatments on biogas production from anaerobic digestion of palm oil mill effleunt. American J. of Eng. and Applied Sciences, 2(1): 139 - 146 .

Tanusri, M. and N. K. Mandal (1997). Comparative study of biogas production from different waste materials. Energy Conters, Mgmt., 38(7): $679-683$.

Wolf, A; M. Watson and N. Wolf (2003). Digestion and dissolution methods for $\mathrm{P}, \mathrm{K}, \mathrm{Ca}, \mathrm{Mg}$ and trace elements, J. Peters 
Recommended methods of manure analysis. University of Wisconsin Extension Publication, A3769.

\section{Yeneneh, A. M; T. K. Sen, S. Chong, H. M. Ang, and A. Kayaalp} (2013). Effect of Combined Microwave-Ultrasonic Pretreatment on Anaerobic Biodegradability of Primary, Excess Activated and Mixed Sludge. Computational Water, Energy, and Environmental Engineering, 2: $7-11$.

\section{الملخص العربي}

زيادة معدل انتاج الميثان خلال الهضم اللاهوائي لروث الحصدئ المئن المنشط باستخدام

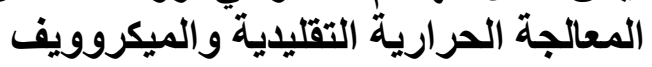

د. هند أحمد مجدى المغاوري' و د. كمال إبراهيم وصفى أحمد'

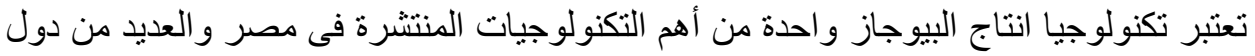

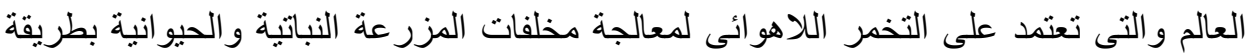
اقتصادية وآمنه صحياً لحماية البيئة من التلوث مع التتاج غاز الميثان كمصدر جديد ومتجدد للطاقة. يهدف هذا البحث الى دراسة تأثير طرق المعالجات الحرارية المختلفة والمتمثلة في المعالجة الحرارية التقليدية والمعالجة الحرارية باستخدام الميكروويف والئف المعالجة الحرارية باستخدام مزيج بينهما وذلك لتنشيط روث الحصان خلال عملية الهضم اللاهوائي بهدف تحسين انتاج

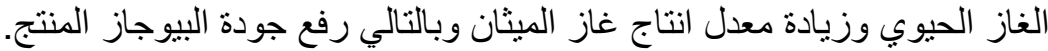
تم تقييم طرق المعالجات الحرارية المختلفة المستخدمة عن طريق قياس التيان معدل انتاج البيوجاز

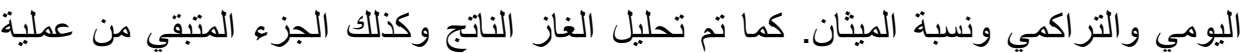

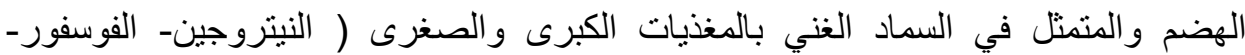

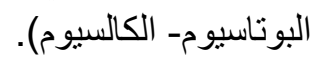

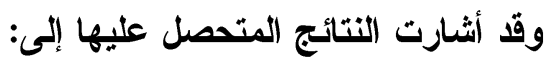

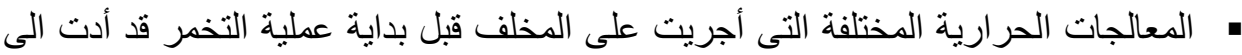

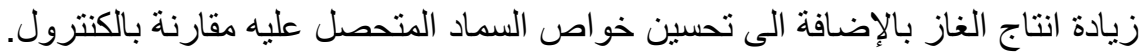

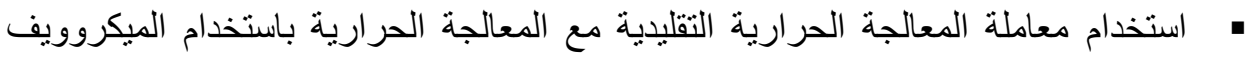

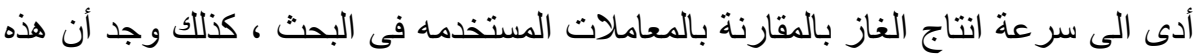

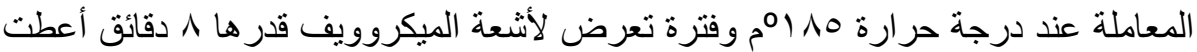

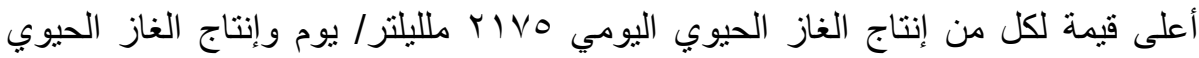

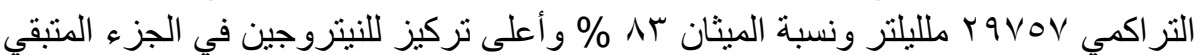
من عملية الهضم 10 .0 \% و المستخدم كسماد. ' مدرس بقسم الهندسة الزراعية - كلية الزراعة - جامعة الزقازيق 